\title{
OPEN
}

Published online: 06 February 2020

\section{Author Correction: Morphological changes of telocytes in camel efferent ductules in response to seasonal variations during the reproductive cycle}

\author{
Fatma M. Abdel-Maksoud (D), Hanan H. Abd-Elhafeez \& Soha A. Soliman \\ Correction to: Scientific Reports https://doi.org/10.1038/s41598-019-41143-y, published online 14 March 2019 \\ The Legend for Figure 10 is incomplete, as it does not specify that the panels for Figure 10b and 10c overlap. As \\ a result,
}

"(A-C) Abundant TCs were identified in the interstitial stroma. TCs had cell bodies (arrowheads) Podomeres were ramified and formed a 3D network, note: epithelium (EP), macrophage."

should read:

"(A-C) Abundant TCs were identified in the interstitial stroma. TCs had cell bodies (arrowheads) Podomeres were ramified and formed a 3D network, note: epithelium (EP), macrophage. Panel 10b shows one telocyte cell under the epithelium (Ep), associated with a macrophage (selected square); Panel 10c provides a more focused image of the same area under the epithelium, showing another telocyte (arrow head) in addition to the previous one."

(c) (i) Open Access This article is licensed under a Creative Commons Attribution 4.0 International (c) License, which permits use, sharing, adaptation, distribution and reproduction in any medium or format, as long as you give appropriate credit to the original author(s) and the source, provide a link to the Creative Commons license, and indicate if changes were made. The images or other third party material in this article are included in the article's Creative Commons license, unless indicated otherwise in a credit line to the material. If material is not included in the article's Creative Commons license and your intended use is not permitted by statutory regulation or exceeds the permitted use, you will need to obtain permission directly from the copyright holder. To view a copy of this license, visit http://creativecommons.org/licenses/by/4.0/.

(C) The Author(s) 2020 